Ssciendo Studia Anglica Posnaniensia 54s1 (2019): 315-336

doi: 10.2478/stap-2019-0015

\title{
CHANGE FROM ABOVE AND RESISTANCE TO CHANGE IN THE EARLY PRESCRIPTIVE PRONOUNCING DICTIONARIES OF ENGLISH*
}

\author{
Nicolas TRAPATEAU ${ }^{1}$ AND JEAN-LOUIS DUCHET ${ }^{2}$
}

\begin{abstract}
To what extent is it possible to interpret the data of pronouncing dictionaries of the $18^{\text {th }}$ century in sociolinguistic terms? Several answers are provided by resorting to Labov's concepts of change from above and change from below the level of awareness. A systematic investigation of John Walker's Critical Pronouncing Dictionary $(1791,1809)$, the most complete and cumulative of all such dictionaries of the time, makes it possible to show that an orthoepist like Walker often reflects the pressure in favour of change from above for vowel quality and resistance to such a change in matters of stress placement. By preferring analogy to conservative pronunciations due to his bias in favour of a rational pattern, Walker also links analogy to the "vernacular instinct", promoting variant forms witnessing a change from below. And many other changes under way in his time, which pass unnoticed in the orthoepist's discourse and transcriptions, properly deserve to be treated as changes from below, thus making his dictionary the common ground for pressures from above and pressures from below.

Walker's prescription is a complex combination of both promotion of, and resistance to pressures from above according to criteria that reflect the ideals of the upper middle class.
\end{abstract}

Keywords: Analogy; change from above; change from below; orthoepy; palatalization; phonological change; pronouncing dictionaries; stress placement; John Walker.

\section{Introduction}

In the second half of the eighteenth century, the increasing geographic and social mobility of middle-rank citizens in the newly united British Kingdom created a

* We wish to thank the two anonymous reviewers and the journal's editors for their helpful comments in the revision of the paper. We also wish to thank Jim Walker and Nikos Lavidas for taking the initiative of the S8 seminar of the ESSE conference in Galway (August 2016) in which the first version of this paper was presented.

$1 \quad$ Université Côte d'Azur, CNRS, UMR 7320 BCL, Nice, France. nicolas.trapateau@univcotedazur.fr

$2 \quad$ Université de Poitiers, EA 3816 FoReLLIS, France. jlduchet@univ-poitiers.fr 
demand for pronunciation guides that would guarantee a better integration into the upper circles of society. This encouraged the publication of pronouncing dictionaries and elocution manuals such as those by Sheridan (1780) and Walker (1791, 1809), who were among the leaders of this elocution movement. These self-declared "orthoepists" aimed at describing the "correct" pronunciation of English words. Their works adopted a prescriptive stance that was a direct answer to linguistically insecure readers willing to adopt the language of the established elite in order to obtain social recognition.

In a number of ways, the prescriptive testimony of these orthoepists is invaluable for the study of language variation and change. If the pronunciation variants that these authors tag as prestigious or undesirable are compared with the standard forms transcribed in today's pronouncing dictionaries (Wells 1990, 2000, 2008), their survival or disappearance in today's main dialects of English can shed light on the direction and process of change.

The abundance of explicit normative comments in John Walker's work naturally led us to examine language change brought by social factors, and specifically what Labov (1994: 78) calls change from above the level of awareness. Unlike most orthoepists who only provide a collection of transcriptions without any comment on their choices, Walker's attitude towards change is regularly made explicit in his discourse. For this study, we have used our own digitization of the 1809 stereotyped edition of Walker's dictionary as a lexico-phonetic database, and we also took into account other contemporary works such as Buchanan (1766), Kenrick (1773), Barclay (1774, 1792), and Sheridan (1780). Our research aims at documenting the role of eighteenth-century orthoepists in the conscious spread of some of the phonetic changes from above in Late Modern English and the resistance against them which is also noticeable in our dictionary data. The questions we want to give an answer to are (i) whether Walker's prescriptions have been successful, and (ii) whether their success or lack thereof was caused by the rational argument of analogy or the learned argument of authority provided by Latin and Greek.

\section{Socio-historical background}

\subsection{Selecting a standard for English pronunciation}

Despite Swift's call for the creation of an academy to regulate the English language (Swift 1712), the idea of a national dictionary was dropped (Beal 2004: 91-92). The standardization of English pronunciation was therefore a slow, intermittent, and haphazard process which depended on the individual works of multiple authors with variable commercial success and increasingly accurate methods of transcribing speech sounds. After Dyche's first attempt to mark stress 
placement in a dictionary with an apostrophe placed after the stressed vowel (Dyche 1723), a number of orthoepic dictionaries followed. As a consequence of the 1707 Act of Union of England and Scotland, increasing geographic and social mobility ${ }^{3}$ brought a number of Scotsmen such as Buchanan (1766), Johnston (1764), or Perry (1775) to describe and promote the pronunciation of "polite speakers" in the capital as a model for the whole Union (Beal 2004: 96).

After the publication of Johnson's dictionary in 1755, which was widely recognized $^{4}$ at that time for finally fixing the orthography of English, there was a need for a work of equal importance that would also fix the pronunciation of that language by indicating stress placement but also the pronunciation of the vowels and consonants of every word. The dictionary proposed by Kenrick in 1773 was soon to be eclipsed by that of Sheridan (1780), a former actor that had turned to elocution and had popularized the discipline by giving a series of lectures around the kingdom (Sheridan 1762) promoting the future publication of his own work.

Despite the fact that he was Swift's godson and a famous actor on the stage, Sheridan's authority on pronunciation was criticized and the author of A Caution to Gentlemen who use Sheridan's Dictionary (1790) accused him of introducing Irishisms. This gave the opportunity for Walker, another actor and teacher of elocution born in the capital, to produce a "critical" dictionary (1791) in order to cumulate and correct the work of his predecessors and rationalize the pronunciation of English into a series of 560 principles. Even though Walker adopts the speech of Londoners ("polite" and "learned" speakers) as an ideal model, he also tries to question the validity of some pronunciations by invoking rational principles such as analogy, which he thought should be the main regulator of pronunciation.

\subsection{Attitudes towards language change}

Ten years before the publication of Walker's dictionary, language prescriptivism was often accompanied by a nostalgia for the Augustan age of Queen Anne at the beginning of the century. This is accounted for historically by Sheridan (1780), in the preface to his dictionary:

There was a time, and that at no very distant period, which may be called the Augustan age of England, I mean during the reign of Queen Anne, when English was the language spoken at court; and when the same attention was paid to propriety of pronunciation, as that of French at the Court of Versailles. This produced a uniformity in that article in all the polite circles; [...]. But on the accession of a foreign family to the throne, amid the many blessings conferred by that happy event, the English language suffered much by being banished the court, to make room for

3 See Houston \& Withers, esp. Table 1 (1990: 296). See also esp. Pouillon (2018: 106, 109).

4 E.g., in the very first sentences of Walker's preface to his Critical Dictionary. 
the French. From that time the regard formerly paid to pronunciation has been gradually declining; so that now the greatest improprieties in that point are to be found among people of fashion; many pronunciations, which thirty or forty years ago were confined to the vulgar, are gradually gaining ground; and if something be not done to stop this growing evil, and fix a general standard at present, the English is likely to become a mere jargon, which every one may pronounce as he pleases.

The lack of a "polite" or "elegant" prescriptive force between 1715 and the late 18 th century seems to have allowed the spread of variants that were formerly associated with lower social ranks. The elocutionists and orthoepists provided norms that the court no longer provided. In so doing, they have filled a gap and set a standard based not only on the pronunciation of the Court (strongly influenced by French during the Restoration period ${ }^{5}$ ) but also on the middle ranks of educated men emerging as a prescriptive force. Sheridan and Walker themselves were part of these social climbers and gained recognition thanks to an acute sense of the differences between the language of the elite they wanted to join and that of the common people. In this regard, their role as potential leaders of change should not be overlooked.

\subsection{Orthoepists and elocutionists as linguistic innovators}

Orthoepists are prescriptivists, and naturally considered as conservative and against language change, ${ }^{6}$ as reflected in their idealization of the English of Queen Anne's time. However, their influence on the public may also accelerate a change towards the generalization of new upper rank pronunciations to other social groups or, in the case of Walker, encourage the use of pronunciations that comply with analogy.

Labov's distinction between change from above and change from below the level of awareness provides a relevant model to account for the changes recommended or resisted by orthoepists. The interpretation given by Labov himself has to be kept in mind:

"Above" and "below" refer here simultaneously to levels of social awareness and positions in the socio-economic hierarchy. Changes from above are introduced by the dominant social class, often with full public awareness. Normally they represent borrowings from other speech communities that have a higher prestige in the view of the dominant class. (1994: 78)

See F. Brunot (1966, vol. 5: 165-168).

See Mugglestone (2003: 80) quoting Walker about the lengthening of [p:] in broth, froth, and moth, as if written brawth, frawth, and mawth: "Though the use of a lengthened sound in this position had in fact been attested for London English from the late seventeenth century, (...) throughout the late eighteenth and nineteenth centuries this shift was nevertheless often depicted as solely the preserve of the 'vulgar', the 'ignorant', or the socially unacceptable". 
A pronouncing dictionary will more naturally provide evidence of changes from above which are discussed among orthoepists and connected to external norms. The phonological cases selected for this study all show a conflict over the spread of a variant which does not comply with usual spelling-to-sound correspondences, or borrows pronunciation features from prestigious classical languages or foreign languages. Most of the pressures from above expressed in Walker's dictionary are based on the ideology that orthography and etymology from the prestigious classical languages should rule pronunciation.

By recommending and imposing changes, orthoepists act as innovators. Labov (2001: 363) quotes Milroy (1992) and Boissevain (1974) about "innovators (someone who introduces a form used by one group to another group)". Boissevain's broker or innovator "appears as a marginal person with high communication scores". This would be an apt description of a figure such as John Walker, a Catholic and a former actor who became very popular among many sections of society ${ }^{7}$ thanks to his public lectures (Mugglestone 2003: 37) and the success of the dictionary. ${ }^{8}$ Orthoepists may therefore be considered as such brokers or innovators.

\section{Corpus}

\subsection{Transcription systems}

Most of the examples analysed in this study, which were all selected for conveying linguistic pressures from above, are extracted from Walker's dictionary (1791) as already mentioned above in 2.3 , but this work is heir to a century-long orthoepic tradition. Earlier dictionaries from the first half of the century such as Dyche (1727) or Johnson (1755) started to indicate minimal information such as stress placement by placing an apostrophe after the stressed vowel or syllable: TO ACCE'PT. Buchanan (1766) was then the first to introduce indications about the realization of vowels and consonants by way of respellings and diacritics as in larynx: lairĭnks. Taking into account all the transcription innovations of their predecessors, Kenrick (1773), Sheridan (1780) and Walker (1791) adopted another way of indicating vowel quality by placing a specific figure ${ }^{9}$ over them, exemplified by Walker in the following list: fa ${ }^{1} \mathrm{te}, \mathrm{fa}^{2} \mathrm{r}, \mathrm{fa}^{3} \mathrm{ll}, \mathrm{fa}^{4} \mathrm{t}$, respectively [e:], [a:r], [p:], [a]. For each graphic vowel number 1 refers to the phonetically long vowels and the highest figures (up to 4) corresponds to the short vowels. Even though Walker's transcription system

\footnotetext{
He was the private tutor of Lord Erskine's and Edmund Burke's sons (Ranson 2002: 54) See Shapiro (2016: xxvii).

Each author had his own figure-to-sound system, so that Walker's a ${ }^{1}$ in fate, fa ${ }^{1}$ te, i.e., [e:], did not correspond to Sheridan's a ${ }^{1}$ in fat , fa ${ }^{1}$, i.e., [a].
} 
is not strictly phonetic compared to 21 st century standards, it is nevertheless reliable as it avoids ambiguous symbols (there: $\mathrm{THa}^{1} \mathrm{re}$, with $\mathrm{TH}$ in capital letters to refer to the voiced version of the consonant whereas th in italics refers to the voiceless consonant) and in some cases his precision is comparable to modern narrow transcriptions. Walker provides the following transcriptions: length: le ${ }^{2}$ ngkth, bench: be ${ }^{2} \mathbf{n s h}$ which correspond to Wells's epenthetic [k] in [le $\left.{ }^{\mathrm{k}} \theta\right]$ and collapsible [t] in [bent]] (Wells 1990).

The transcription system which Walker adopts is therefore the result of cumulative transcriptional innovations. This also implies some degree of imitation among dictionary makers. Most of the dictionaries published after Johnson relied heavily on his word list. Walker's work was no exception but it represented the most refined version of pronouncing prescription available at the time. Three features make it a unique work of reference:

- it provides no less than 560 principles which are quoted and cross-referenced in the dictionary entries;

- it is cumulative in providing a detailed account of competing views among orthoepists and his dictionary;

- it is the only one which provides detailed comments in more than one thousand remarks at the end of each entry revealing conflicts between authorities. It had no real competitor during the following century and was regularly reprinted until the beginning of the next (Mugglestone 2003: 32).

\subsection{Walker's dictionary}

Our research has been conducted on a database stemming from a fully computerized re-edition (Trapateau 2015) of John Walker's Critical Pronouncing Dictionary and Expositor of the English language $(1791,1809)$ and providing exhaustive lists of lexical units belonging to a lexical set or to a stress pattern.

Walker's Critical Pronouncing Dictionary in its 1809 edition, published shortly after the author's death with all the corrections he had made and recommended, includes 38,768 entries, with a phonetic transcription and stressmarks, which make it comparable in size and quality to the pronouncing dictionaries of the $20^{\text {th }}$ century.

The transcriptions provided illustrate the prescriptivism of the orthoepists of the second half of the $18^{\text {th }}$ century. It offers the prescription of the "best usage" on the basis of a critical comparison of previous dictionaries ${ }^{10}$ of the century (see example (1) below), most of them based on Johnson's word list and definitions.

10 Buchanan (1766), Sheridan (1780), and Perry (1775), among others, are often referred to as "authorities" on pronunciation. 
(1) BREVIARY, bre ${ }^{1} \mathrm{ve}^{\prime}-\mathrm{ya}^{4}-\mathrm{re}^{1}$, s. 507. An abridgment, an epitome [...]. All our orthöepists but Mr. Perry pronounce the first syllable of this word long; but if authority were silent, analogy would decide for the pronunciation I have given, 534. (Walker 1809, s.v. BREVIARY)

What makes Walker's dictionary an ideal source to explore the historical sociolinguistics of English is that it is not a mere collection of dumb transcriptions. Its entries are enriched with around 1115 metalinguistic comments on pronunciation or spelling (introduced by a pointing hand placed after the regular lexicographic content of the entry). In these critical remarks, (such as that of example (1) above) it is possible to correlate the critical data with sociolinguistic judgements emanating from three different sections of society. And it gives evidence of changes occurring in the pronunciation of the time, which can be interpreted in terms of change from above and change from below. Some of these comments are based on rational principles of pronunciation tested on exhaustive lexical sets and outlined in the front matter of the dictionary, such as Principle 507, referred to in example (1):

507. Nothing can be more uniform than the position of the accent in words [which have $i a$ in their termination]; and, with very few exceptions, the quantity of the accented vowel is as regular as the accent ; for when these terminations are preceded by a single consonant, every accented vowel is long, except $i[\ldots]$. (Walker 1809: 76)

Other comments contain picturesque stigmatizations tinged with phonaesthetic judgements of the time:

(2) COLONEL, $\mathrm{ku}^{2} \mathrm{r}^{\prime}-\mathrm{ne}^{2} 1, s$. The chief commander of a regiment. This word is among those gross irregularities which must be given up as incorrigible. (Walker 1809 , s.v. COLONEL)

Trapateau (2015) has shown that Walker balances the positive and negative characteristics of three idealized groups of speakers: the 'learned', the 'polite', and the 'vulgar'. Whilst learned and polite and their synonyms are positive terms referring to intellectuals and members of the higher social classes respectively, vulgar is a negative epithet for the common people. But the usage of the learned is sometimes condemned by Walker as pedantic, and that of the polite as affected, whilst he acknowledges the 'vernacular instinct' of the common people: 
(3) PLUMP, plu²mp, s. A knot, a tuft, a cluster, a number joined in one mass. Little used.

This word, says Mr. Mason, ${ }^{11}$ is now corrupted to Clump and is one of those words that the vulgar continue to speak right, and for which they are laughed at by politer corrupters of language. (Walker 1809, s.v. PLUMP)

When a linguistic variant present in lower-class speech better complies with orthography than any other variant, Walker does not hesitate to recommend it. Even though in that case compliance with orthography is likely to reflect a pressure from above the level of consciousness, Walker attributes this phenomenon to an instinctive competence among lower class people.

\section{Phonological changes and loanword integration}

\subsection{Analogy and the treatment of loanwords}

The 'vernacular instinct' of the lower classes is also directly related to the principle of analogy which guides Walker in choosing between variant pronunciations, and which shows a good intuition of the variants which were to prevail in the 19th and 20th centuries. Here, the vernacular instinct consists in processing a loanword exactly as any word of a similar shape in the native vocabulary, without any influence from the original language.

A clear illustration of this situation is brought by the dictionary entry for the word vertigo which has three competing pronunciations, two of which are the consequence of a pressure from above to borrow features from classic or Romance languages: "learned" and "fashionable" (with penultimate stress), as opposed to "the genuine English analogy" (with antepenultimate stress). In spite of his preference for the latter, Walker finally yields to the former in his Dictionary by placing the learned pronunciation first. ${ }^{12}$

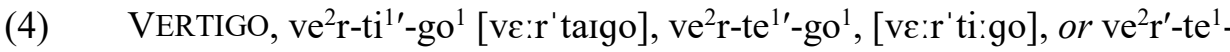
go $^{1}$, ['ve:rtigo], s. 112. A giddiness, a sense of turning in the head. This word is exactly under the same predicament as Serpigo and Lentigo. If we pronounce it learnedly, we must place the accent in the first manner, 503. If we, pronounce it modishly, and wish to smack of the French or Italian, we must adopt the second ; but if we follow the genuine English analogy, we must pronounce it in the last manner. - See Principles, No. 112. . (Walker, 1809, s.v. VERTIGO)

12 Right after Walker's transcription we provide between square brackets our reconstruction of the pronunciation of the time, i.e., when $[\varepsilon:]$ and $[0:]$ had not yet been centralized to [3:] and [əo]. 
For each pronunciation Walker quotes as authorities the authors of other pronouncing dictionaries which were published between the middle and the end of the 18th century:

The authorities for the first pronunciation are, Mr. Elphinston ${ }^{13}$, Mr. Sheridan, Bailey, and Entick ; for the second, Dr. Kenrick, Mr. Nares, Mr. Scott, and W. Johnston ; and for the third, Dr. Johnson, Dr. Ash, Mr. Perry, Buchanan, Barclay, and Fenning. This too was Swift's pronunciation, as we see by Dr. Johnson's quotation :- "And that old vertigo in's head, "Will never leave him till he's dead." (Walker 1809, s.v. VERTIGO)

Using Johnson's authority he reveals his own tendency to prefer a trend which will bring a change from below paving the way to today's pronunciation ['v3:tigəo] which has prevailed since:

\begin{abstract}
In this word we see the tendency of the accent to its true centre in its own language. Vertigo with the accent on the $i$, and that pronounced long as in title, has so Latin a sound that we scarcely think we are speaking English; this makes us the more readily give in to the foreign sound of $i$, as in fatigue. This sound a correct English ear is soon weary of, and settles at last with the accent on the first syllable, with the $i$ sounded as in indigo, portico, \&c. ${ }^{14}$ (Walker 1809, s.v. VERTIGO)
\end{abstract}

We may therefore interpret Walker's discourse both as the expression of the current pressure from above to prefer a learned pronunciation based on the way the Latin etymon was pronounced by people who knew Latin, and the emerging pressure from below to change the pronunciation pattern on the basis of an analogical treatment of lexical series regardless of the etymologically informed pressure of the learned. Analogy in this case is clearly leading a change from below.

\title{
4.2. Phonological changes
}

The non-integration of a loanword like vertigo is directly linked to a conscious imitation of the speech of prestigious social groups who knew foreign languages. We therefore interpret the success of such a variant over time as a change from above. On the contrary, the ousting of such forms in favour of dominant vernacular patterns of pronunciation should be interpreted as a change from below, which is the case today in vertigo. Our data shows that the changes in stress placement that occurred after the 18th century were often a resolution of such conflicts between Latin and vernacular stress patterns.

13 Elphinston (1765: 174), Bailey (1727), Entick (1780), Nares (1784: 28), Scott (1786), Ash (1775), Fenning (1761).

14 That is, with a short [i] as in the final vowel of happy, the only possibility in open syllables in Walker's pronunciation. 
The phenomenon of palatalization is also regularly discussed in Walker's critical discourse, and gives rise to a number of graphocentric remarks. Similarly, the success of a variant that goes against a phonotactic process like palatalization (the word tube pronounced [tju:b] instead of [t $\mathrm{fu}: \mathrm{b}]$ ) and consciously preserves a closer equivalence between phonemes and graphemes could be interpreted as a change from above.

Surprisingly, a number of changes known to have occurred in the eighteenth century and that have been described in Beal (2004), Dobson (1968), and Jones (2006) are hardly documented in Walker's dictionary:

- the stabilization of $[\Lambda]$ instead of short $[\mathrm{u}]$ as in $c u t$, shut, love.

- the change from [a] to [a] before voiceless fricatives as in staff, path, pass.

- the gradual weakening of $[\mathrm{I}]$ or $[\mathrm{r}]$ in postvocalic position as in car, part (creating a non rhotic variety of English). ${ }^{15}$

They are most probably the product of changes from below which pass unnoticed and remain "completely below the level of social awareness" (Labov 1994: 78). The rounding of /a/ discussed in section 5.4 is an example of such a type of change.

Mergers also belong to that category, although Walker explicitly resists the phonological merger of the vowels of TERM and NURSE. This probably means that this change from below was about to be complete, as according to Labov (1994: 78), it is the only moment when members of the community may become aware of it.

5. Success and failure of pressures from above

\subsection{Changes in stress placement}

Walker resists a number of pressures from above to stress the penultimate syllable of words such as European, inimical, indecorous or abdomen in keeping with their etymological origin. Examining the case of European, Walker writes:

\footnotetext{
This word, according to the analogy of our own language, ought certainly to have the accent on the second syllable ; and this is the pronunciation which unlettered speakers constantly adopt ; but the learned, ashamed of the analogies of their own tongue, always place the accent on the third syllable, because Europceus, has the penultimate long, and is therefore accented in Latin. (Walker 1809, s.v. EUROPEAN)
}

The stress-pattern Eu'ropean is superseded by the Latin stress pattern in Euro'pean. The reason is that most adjectives in -ean have a learned pronunciation with little currency outside learned circles.

15 See Lass (1999: 89, 104, 114). 

Euro'pean
euro'pōus
colos 'sean
colos'sēus

This remains true when adjectives in -ean are stressed on the antepenultimate because the Latin etymon has a short $\breve{e}$ before the ending:

$\begin{array}{ll}\text { Mediter'ranean } & \text { mediter'raněus } \\ \text { mar'morean } & \text { mar'morěus }\end{array}$

The learned stress pattern on the pre-final vowel, inspired by the stress placement rules of Latin, has prevailed in the first two cases, contrary to the general tendency to stress the syllable preceding the hiatus ('ocean, 'nation). This is typically a change from above, as it prefers Latin etymology to analogy with the dominant stress pattern of the lexical set of words in -ion.

The adjective inimical is mentioned by Walker as having two stress patterns: one is $i^{2} n-i^{2} m^{\prime}-e^{1}-k a^{4} l\left[I^{\prime} n r m i k^{2} l\right]$, and the other is $i^{2} n-e^{1}-m^{1}{ }^{1}-k^{4}{ }^{4} l$ [, mi' mark $\left.{ }^{2} l\right]$. The latter is, Walker writes, "an oddity" made "fashionable" by the "vanity of showing its derivation from the Latin ïnimīcus". This change is resisted by Walker who bases his judgement on the analogy principle: "An Englishman who had never heard it pronounced would at first sight have placed the accent on the antepenultimate and have pronounced the penultimate $i$ short." (Walker 1809, s.v. INIMICUS)

Similarly the adjective indecorous is stressed on the penultimate and this time Walker puts this stress pattern first: $i^{2} n-d^{1}-k^{11}{ }^{\prime}-r^{2} s$ [, Indi 'ko:rəs] yielding to the pressure from above. But he adds ironically that

[...] because the Latin adjective indecorus has the penultimate long, and consequently the accent on it, we must desert our own analogy and servilely follow the Latin accentuation [which has] no regard to analogy [...]. Dr Ash is the only one who places the accent on the antepenultimate of this word: but what is his single authority though with analogy on his side, to a crowd of coxcombs vapouring with scraps of Latin? (Walker 1809, s.v. INDECOROUS)

Walker illustrates here the conflict between the pressure from above and the pressure from below.

One more example will provide further evidence. The three nouns abdomen $\mathrm{a}^{4} \mathrm{~b}-\mathrm{do}^{11}-\mathrm{me}^{2} \mathrm{n}$, acumen $\mathrm{a}^{4}-\mathrm{ku}^{11}-\mathrm{me}^{2} \mathrm{n}$, bitumen $\mathrm{be}^{1}-\mathrm{tu}^{11}-\mathrm{me}^{2} \mathrm{n}$ are stressed by Walker on the second syllable, which is no longer the case now. 
Table 1 -Abdomen, acumen, and bitumen in 18th century and present-day English.

\begin{tabular}{l|c|c|c}
\hline & $\begin{array}{c}\text { 18th century } \\
\text { English } \\
\text { (Walker 1791) }\end{array}$ & $\begin{array}{c}\text { Present-day RP } \\
\text { (Wells 2008) }\end{array}$ & $\begin{array}{c}\text { Present-day GA } \\
\text { (Kenyon \& Knott 1945) }\end{array}$ \\
\hline abdomen & [ab'do:men] & ['æbdəmən] & ['æbdəmən] or [æb'domən] \\
\hline acumen & [a'kju:men] & ['ækjomən] & [ə'kju:mən] \\
\hline bitumen & [bi'tju:men] & ['bitfomin] & [bə'tu:mən] \\
\hline
\end{tabular}

These words would have "the accent on the first syllable if the learned had not stepped in to rescue these classical words from the invasion of the Gothic accent and to preserve the stress inviolably on the second syllable" (Walker 1809, Principle 503, b); bitumen with the stress on the antepenultimate "may be considered as the most common, ${ }^{16}$ though not the most learned pronunciation" (Walker 1809, s.v. BITUMEN).

Here again, although he disseminates the influence of learned people following the Latin stress pattern (abdōmen, bitūmen, acūmen), Walker shows in his devastating irony a strong resistance to changes from above and, again, favours a complete integration of the loanword borrowed from Latin. What is striking in this case is that British English, following Walker's intuition, has successfully resisted this change, while American English has followed the change from above revealed by Walker's dictionary (see Kenyon \& Knott 1945). This might provide hints as to the role of learned prescription and of written culture in the development of specific American pronunciations at the beginning of the $19^{\text {th }}$ century.

There are other three-syllable words ending in -men in Walker's Dictionary: cerumen $\mathrm{ce}^{1}-\mathrm{ru}^{11}$-men [si'ru:men] (with a reference to the entry for bitumen), examen $\mathrm{e}^{2} \mathrm{gz}-\mathrm{a}^{1}{ }^{\prime}-\mathrm{me}^{2} \mathrm{n}$ [ $\mathrm{gg}^{\prime} \mathrm{ze}: \mathrm{men}$ ] (with a reference to principle 503), legumen le $\mathrm{e}^{1}$ $\mathrm{gu}^{1}{ }^{1}-\mathrm{me}^{2} \mathrm{n}$ [li'gju:men] (with a reference to principle 503, and to the entry for bitumen), all of them stressed on the second syllable. ${ }^{17}$ But there are also regimen $\mathrm{re}^{2} \mathrm{~d}^{\prime}-\mathrm{je}{ }^{1}-\mathrm{me}^{2} \mathrm{n}$ [' $\left.\mathrm{r} \varepsilon \mathrm{d} z \mathrm{im} \varepsilon \mathrm{n}\right]$ and specimen $\mathrm{spe}^{2} \mathrm{~s}^{\prime}-\mathrm{se}^{1}-\mathrm{me}^{2} \mathrm{n}$ [' on the first syllable and in which the Latin stress rule is respected since the penultimate $<\mathrm{i}>$ in regimen and specimen is short in Latin and both words are stressed on the antepenultimate. Therefore, the "invasion of the Gothic accent" also rests upon the Latin stress pattern of trisyllabic words the second syllable of which has a short vowel. This is a mixed case of a change from below involved in a conspiracy with a change from above, since here, both English analogy and Latin stress rules lead to the placement of stress on the antepenultimate.

\footnotetext{
16 Minsheu (1617) mentions a word bitume, obviously borrowed from French, with stress on the first syllable.

17 Here again we have provided a transcription of the sounds as they were pronounced by Walker, and not as they are today.
} 
Disyllabic verbs in -ate undergo at the end of the $18^{\text {th }}$ century an important stress shift. Walker transcribes all these verbs with the stress on -ate when they are prefixed (re late, in 'flate), and with the stress on the first syllable when they are not ('dictate, 'castrate, 'stagnate). The only exception is cre'ate, the oldest verb in this class. Barclay's Dictionary (1774) provides evidence of a change under way: in his 1792 edition he stresses these verbs as follows: 'narrate, 'vacate and also transcribes 'vacated; in the 1799 edition an innovation occurs: 'narrate, 'vacate but va'cated; finally, the 1824 edition provides evidence of the change being completed: nar 'rate, $v a$ 'cate and va'cated. This change which again occurs in British English only is based on analogy and appears to be a change from below the perception of which has been somewhat haphazard in Barclay's dictionary.

In the $18^{\text {th }}$ century trisyllabic verbs in -ate belong to two types: those with a prefinal consonant cluster which have penultimate stress (com'pensate, con 'template, con 'fiscate), due to the application of the Latin stress rule which places stress on a heavy penultimate syllable; and those without such a consonant cluster which have antepenultimate stress ('tolerate). The change which is going to take place in the $19^{\text {th }}$ century by generalizing the antepenultimate stress pattern had already begun by Walker's time. It is already evidenced by Kenrick (1773): 'confiscate, against Johnson's testimony: con'fiscate. The extension of the antepenultimate stress pattern is still considered "incorrect" by Walker but not very strongly stigmatized. In the entry for the verb contemplate he writes that "there is a very prevailing propensity to pronounce this word with the accent on the first syllable; a propensity which ought to be checked by every lover of the harmony of the language". In this case Walker still sticks to the learned tradition and does not show his usual support of the vernacular taste for analogy and unconscious language changes.

\subsection{Palatalization and reluctance to palatalize}

The palatalization of consonants before [i] and [ju] is already under way at the end of the 18th c.: Walker's principle 294 (see in 3. above) and his remark after the entry for Indian show that three stages of the process are identified in unstressed syllables:

294. If the $y$ be distinctly pronounced, it sufficiently expresses the aspiration of the $d$, and is, in my opinion, the preferable mode of delineating the sound, as it keeps the two last syllables from uniting too closely. Where analogy, therefore, is so clear, and custom so dubious, we ought not to hesitate a moment at pronouncing odious, tedious, perfidious, fastidious, insidious, invidious, compendious, melodious, commodious, preludious, and studious, as if written o-je-ous, te-je-ous, or rather ode-yus, tede-yus, $\& \mathrm{c}$; nor should we forget that Indian comes under the same analogy, and ought, though contrary to respectable usage, be pronounced as if written Ind-yan, and nearly as In-je-an, 376. (Walker 1809: 49). 
(6) INDIAN, $i^{2} n^{\prime}-\mathrm{de}^{1}-\mathrm{a}^{4} \mathrm{n}$ ['in.di.en], or $\mathrm{i}^{2} \mathrm{n}^{\prime}-\mathrm{je} \mathrm{e}^{1}-\mathrm{a}^{4} \mathrm{n}$ ['In.dzi.en], or $\mathrm{i}^{2} n \mathrm{n}^{\prime}-\mathrm{ya}^{4} \mathrm{n}$ ['Ind.jen], s. 88. 294. A native of India. (Walker 1809, s.v. INDIAN). ${ }^{18}$

Although syllable compression is stigmatized, palatalization in the unstressed hiatus or the lack thereof both seem equally acceptable.

At the end of the $18^{\text {th }}$ century, the verb educate is transcribed $\mathrm{e}^{2} \mathrm{~d}^{\prime}-\mathrm{ju} \mathrm{u}^{1}-\mathrm{ka} \mathrm{a}^{1}$ te ['edzukert], just as in the latter part of the $20^{\text {th }}$, and, according to Walker, education is "elegantly pronounced ed-jucation." [, edzu'keIfən] (Walker 1809: 57, Principle 376). However, late $19^{\text {th }}$ century dictionaries such as Craig (1859) and Cooley (1861), and the Jonesian tradition of the $20^{\text {th }}$ century definitely prefer education with [, edju-] and this rejection of the palatal affricate may be interpreted as a subsequent change from above. But the American variant does have [d3] in the $20^{\text {th }}$ century as evidenced by Kenyon \& Knott (1945) and Wells (1990), though Webster's dictionary (1841) seemed to ignore it. It is only with Jones's $15^{\text {th }}$ edition (1997, edited by Peter Roach) that the palatal affricate is recognized in British English as the most frequent and acceptable pronunciation in words like educate and education.

Words in -dure show a more generalized palatalization: ordure $\mathrm{o}^{3} \mathrm{r}^{\prime}$-ju ${ }^{1} \mathrm{re}$, verdure $\mathrm{ve}^{2} \mathrm{r}^{\prime}$-ju ${ }^{1} \mathrm{re}$, procedure pro $^{1}-\mathrm{se}^{1} \mathrm{e}^{11}-\mathrm{ju} \mathrm{u}^{1} \mathrm{re} .{ }^{19}$ So do words in -sure : censure $\mathrm{se}^{2} \mathrm{n}^{\prime}$-shu ${ }^{1} \mathrm{re}$, measure $\mathrm{me}^{2} \mathrm{zh}^{\prime}-\mathrm{u}^{1} \mathrm{re}$, pressure $\mathrm{pre}^{2} \mathrm{sh}^{\prime}$-shu ${ }^{1} \mathrm{re}$. The data collected by Beal \& Sen (2015) proves that a following $/ \mathrm{r} /$ constituted a favourable context for palatalization as early as the $18^{\text {th }}$ century.

The resistance to palatalization is more marked in the case of the -ture ending, which also shows that change is under way: literature, discomfiture, investiture, judicature have [tj] whereas capture, future, picture, comfiture, architecture are transcribed with the palatal fricative : -tshu ${ }^{1}$ re [t fju.t. Nunciature provides an interesting case: $n^{2} n^{\prime}-s^{1}-a^{4}-t^{1}$ re ['nınfiatjur]. Palatalization of [sj] is generally allowed but not that of [t $\mathrm{j}]$ in the -ture ending. Given the items considered, a conservative influence rejecting the palatal affricate is still felt in words most used in learned circles (e.g., discomfiture, nunciature) while palatalization is more widespread in lower circles (e.g., comfiture, picture).

What is furthermore worth noticing in Walker's transcriptions is that in all ure endings the vowel is never centralized, with the only exception of injure $\mathrm{i}^{2} \mathrm{n}^{\prime}$ $\mathrm{ju}^{2} \mathrm{r}$ and conjure, which indicates that palatalization occurred before the centralization of the final vowel which follows the palatalized consonant and may not be interpreted as conditioned by it.

18 The unstressed $a$ in the last syllable was in Walker's time more open than the central [ə] which is its twenty-first century reflex.

19 The contemporary pronunciation of these words shows the same palatalized affrication: ['odzoə], ['v3:dzə], [prə'si:dzə]. 
There is another type of palatal change which was treated very differently. In 1791 Walker strongly reacted against the palatalization and against the palatal glide deletion in stressed syllables, as in the noun duke pronounced [du:k] or [dzu:k] "as if written jook: this is not so vulgar as the former". Walker blames his contemporary Sheridan $(1780,1789)$ for such a 'vulgarism':

\begin{abstract}
"But Mr. Sheridan's greatest fault seems to lie in not attending to the nature and influence of the accent : and because nature, creature, feature, fortune, misfortune, $\& \mathrm{c}$. have the $t$ pronounced like $c h$, or $t s h$, as if written crea-chure, fea-tshure, \&c. he has extended this change of $t$ into $t c h$, or $t s h$, to the word tune, and its compounds, tutor, tutoress, tutorage, tutelage, tutelar, tutelary, \&c. tumult, tumour, \&c. which he spells tshoon, tshoon-eble, \&c. tshoo-tur, tshoo-triss, tshoo-tur-idzh, tshoo-teler, tshoo-tel-er-y, \&c. tshoo-mult, tshoo-mur, \&c. Though it is evident, from the foregoing observations, that as the $u$ is under the accent, the preceding $t$ is preserved pure, and that the words ought to be pronounced as if written tewtor, tewmult, tewmour, \&c. and neither tshootur, tshoomult, tshoomour, as Mr. Sheridan writes them, nor tootor, toomult, toomour, as they are very often pronounced by vulgar speakers." (Walker 1809: 67, Principle 462).
\end{abstract}

Walker's pronouncement made Sheridan's editors change the transcription: the early editions $(1780,1789)$ document a palatalization under stress, but after the publication of Walker (1791), Sheridan's 4th edition (1797) shows no indication of palatalization, as shown in Figure 1.

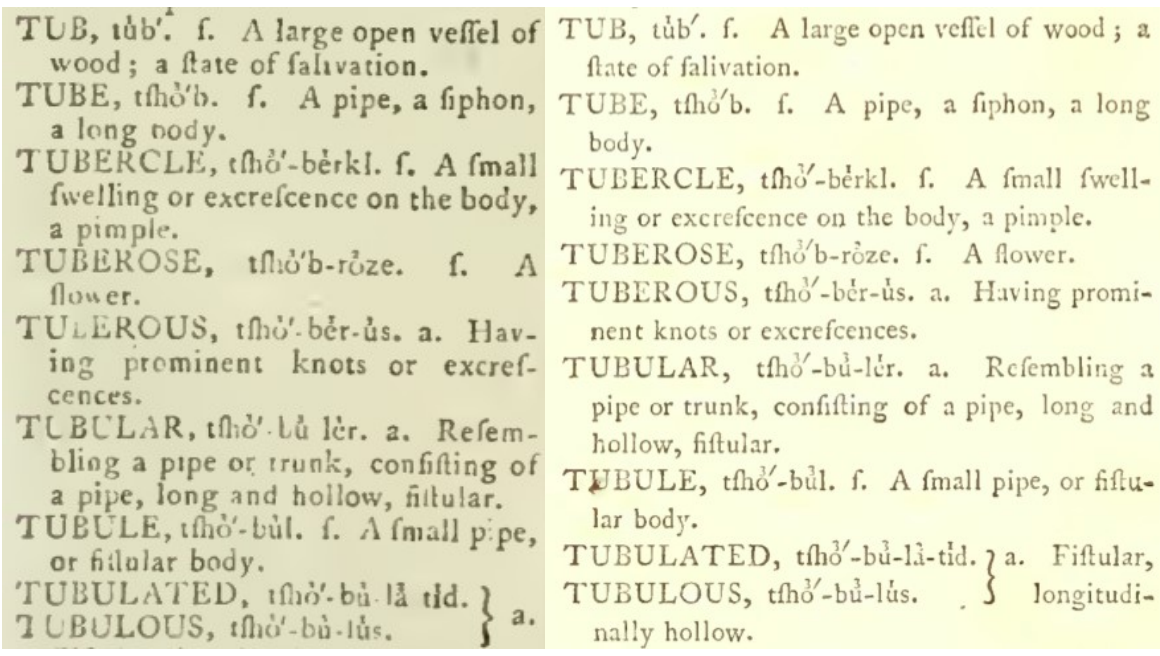




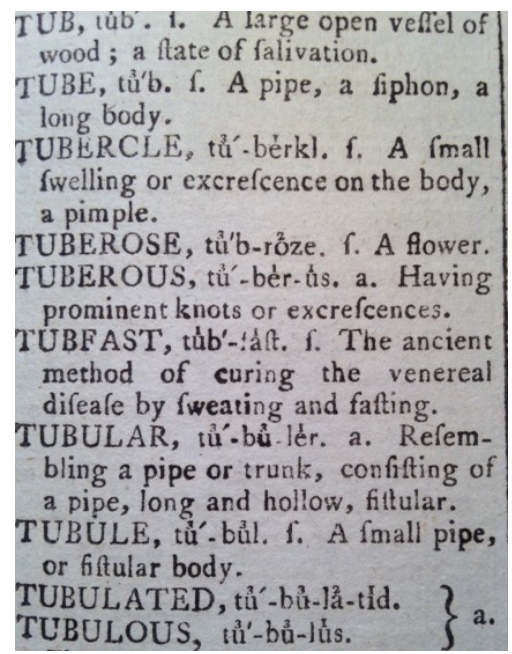

Sheridan (1797)

Figure 1 - Sheridan's transcriptions of words beginning in $t u b$ - in his first three editions.

This argument between orthoepists is in itself an example of a change from above since Sheridan's posthumous editors preferred to conform to the unpalatalized pronunciation recommended by Walker, closer to dominant graphophonemic correspondences.

The other change affecting the sequence of a coronal consonant and the "long" $u$ is the deletion of the palatal glide evidenced but stigmatized in Walker's time. It appears that what we interpret as a change from below is frequent in American English (tube [tu:b]) but not in British English (tube [tju:b]).

\subsection{Vowels before $/ \mathrm{r} /$}

The data of late Modern English dictionaries shows that a change from above favouring a spelling pronunciation [ $\varepsilon$ :] based on the graphic $<\mathrm{e}>$ ousted the historical pronunciation of merchant, with [a:] still shown by clerk or sergeant. It is true that spelling often reflects the pronunciation of the language the word was borrowed from, or a pronunciation of the word in earlier stages of the history of the language. The prescriptive reaction against a new pronunciation which has crept in from below the level of awareness is likely to be justified on the basis of the spelling. And it is a widely accepted principle among lexicographers and orthoepists of the $18^{\text {th }}$ century that pronunciation should be as close as possible to the spelling. 
According to Walker, the word merchant was pronounced by lower-class speakers with [a:] as in clerk. The spelling pronunciation which prevailed,

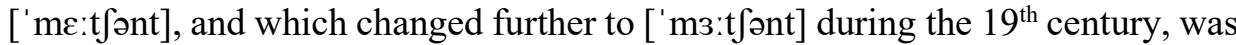
the result of a learned preference based on the spelling that English had inherited from French and which was reflected in the Middle English pronunciation of the word. The same is true of a few other words such as serge or verjuice, which Buchanan (1766) pronounced [sa:rd3] and [va:rdzus]. A few decades later, a change from above, tacitly confirmed by Walker, imposed a spelling

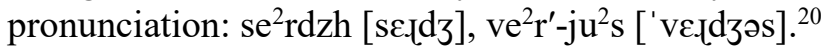

A similar type of opening was found in the word errand, $a^{4} r^{\prime}-r^{4} n d$ ['arand], which had a short [a] because of the syllable structure. While recording the open vowel, Walker suggests a higher variant ['Erand] based on the $<\mathrm{e}>$ spelling, saying that the word "might perhaps, without pedantry, be more properly pronounced as it is written".

However in the case of clerk, serjeant/sergeant, the pressure in favour of a change from above has not been successful: the change from below was already an accomplished fact and the [a:] accepted as correct. The same is true with proper nouns which have a tendency for conservatism both for pronunciation and spelling: Derby, Berkeley, are still pronounced with /a:/ while spelt with $<\mathrm{e}\rangle$. In berberry Walker reports the spelling of the time with $<\mathrm{er}>$ but with the same pronunciation with $\mathrm{a}^{2}$ [a:], which has now become the rule with a regularized spelling (barberry).

The same pressure from above was then invoked by orthoepists in order to resist the merger of this new vowel with that of nurse /3:/ (TERM-NURSE merger according to Wells (1982: 199-200)).

(7) MERCY, $\mathrm{me}^{2} \mathrm{r}^{\prime}-\mathrm{se}^{1}, s .95$. Tenderness, clemency, unwillingness to punish ; pardon; discretion, power of acting at pleasure.

The vulgar pronounce this word as if spelled marcy. Many above the vulgar pronounce it as if spelled murcy; but there is a delicate shade of difference between this and the true sound of $e$, which must be carefully attended to. (Walker 1809, s.v. MERCY)

The distinction between mercy and murcy in Walker's transcription amounts to a difference between [me.t] and [m3.]], which shows that the speakers "above the vulgar", while avoiding the lower-class variant [ar] in mercy, were the leaders of another sound change, i.e., the merger of $/ \varepsilon: /($ spelt $<$ er $>$ ) and $/ 3: /($ spelt $<$ ur $>)$. In more than one respect this is a change from above combining the phasing out of

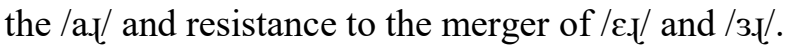

20 Here again the front vowel $[\varepsilon]$ had not yet been centralized to the $[3:]$ heard in present-day RP. 


\subsection{The rounding of /a/}

As the preceding examples have shown, pressures from above are often an attempt to regularize the pronunciation of a vowel under the dominant graphophonemic correspondences of the language. A phenomenon such as the rounding of $/ \mathrm{a} / \mathrm{a}$ change led by the phonetic environment (the preceding [w]), moving a word like watch away from the TRAP set and merging it with that of LOT, was perhaps likely to be noticed by the most spelling-conscious speakers. But it passed unnoticed, which shows it occurred below the level of awareness of speakers.

Henry C. Wyld writes that:

we can show that in the eighteenth century, in good society, people said [kwæliti] and [kwæntiti]. The former types have simply been discarded and their places have been taken by others whose predecessors existed in the eighteenth century side by side with those first mentioned, although at that time they did not happen to be the forms in fashionable use (Wyld 1906: 308).

And indeed we have found that orthoepists at the end of the century (Sheridan and Walker) provide evidence of the change from [a] to [p] in words such as quality $\mathrm{kwo}^{4} \mathrm{l}^{\prime}-\mathrm{le}^{1}-\mathrm{te}^{1}$ or quarrel $\mathrm{kwo}^{4} \mathrm{r}^{\prime}-\mathrm{ri}^{2} 1$, while Buchanan (1766), one generation earlier, prefers [a] $]^{21}$ :

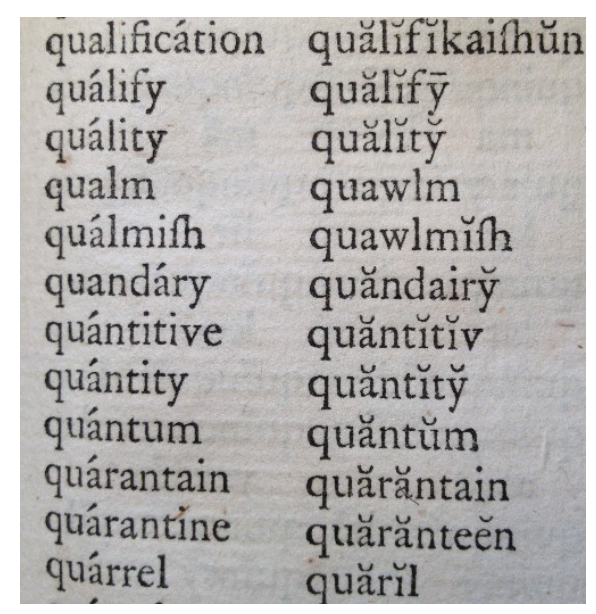

Figure 2 - Buchanan (1766: s.v. qualification)

21 Except for the monosyllable qualm and its derivative qualmish, which show a rounded vowel. 
What Wyld suggests is the existence in a given environment of a neutralization of the contrast between /a/ and /o/, with a broad range of free variants. And little by little a preferred variant, i.e., [p], has become the only realization possible, a situation witnessed by Walker (1791) and Sheridan (1780).

This change from below, unobserved by the speakers themselves, has not given rise to any reluctance or prescriptive reaction, unlike the TERM-NURSE merger. This change might therefore have been completed much earlier than the publication of Sheridan and Walker's dictionaries, which could explain why those authors and speakers of the same generation did not feel the need to come back to a spelling pronunciation.

\section{Conclusions}

Because Walker does not wish to blindly prescribe the pronunciations of high social ranks, he writes somewhat resignedly but not without irony that "in language as in many other cases, it is safer to be wrong with the polite than right with the vulgar." But this attitude may vary according to the different aspects which Walker takes into consideration.

$1^{\circ}$ ) For stress placement: even though he has to consent to the prevailing usage of his time as reflected by the dictionaries he critically examines, he has passing remarks or ironical statements which do express nonconformist views encouraging his readers to resist changes from above based on Latin etymology. He seems to be a supporter of the analogy principle which is spontaneous among the lower classes and often corresponds to his rationalizing view of language matters. Except for a few examples belonging to higher registers such as European, most of the items examined in this study have shifted to the analogical pronunciation advocated by Walker, especially in today's British English. In this domain Walker can be seen as an influential innovator promoting the changes from below emerging in his time.

$2^{\circ}$ ) For palatalization and vowel quality, Walker is far more sensitive to the negative or positive values attached to the variants. In this field, his dictionary confirms and endorses some changes from above based on spelling such as the regularization of the stressed vowel of mercy. While the pressure from above to preserve the yod in stressed syllables is still very strong in present-day RP, palatalization in unstressed contexts only made its way into standard speech in recent years, long after Walker's recommendations.

Our data represent an invaluable testimony of changes from above and changes from below. The analogical changes, which for the prescriptive author are consciously inspired by rational principles, are completely internalized by common speakers. Prescription in orthoepic dictionaries, and particularly in Walker's dictionary, is not designed only to preserve established pronunciations 
or to prescribe changes from above, but also to make acceptable and even popularize a number of changes from below, as long as these could bring language to an idealized regularity much sought after in the Age of Reason.

\section{REFERENCES}

Anonymous. 1790. A caution to gentlemen who use Sheridan's Dictionary (3rd edn). London : G. Bourne and R. \& T. Turner.

Ash, John. 1775. The new and complete dictionary of the English language. London: E. \& C. Dilly.

Bailey, Nathan. 1727. An orthographical dictionary, shewing both the orthography and the orthoepia of the English tongue. London: T. Cox.

Barclay, James. 1774, 1792. A complete and universal English dictionary on a new plan. London : Richardson et al.

Beal, Joan C. 2004. English in modern times, 1700-1945. London: Arnold.

Beal, Joan C. \& Rajan Sen. 2015. En[dj]uring [t]]unes or ma[tj]ure [d]]ukes? Palatalization in eighteenth-century English: Evidence from the Eighteenth-Century English Phonology Database. Paper presented at the 9th Studies in the History of the English Language Conference (SHEL-9), Diachronic Phonology Workshop. Vancouver, Canada, 5-7 June 2015.

Boissevain, Jeremy. 1974. Friends of friends: Networks, manipulators, and coalitions. Oxford: Blackwell.

Brunot, Ferdinand. 1966. Histoire de la langue française des origines à 1900. Paris: Armand Colin.

Buchanan, James. 1766. An essay towards establishing a standard for an elegant and uniform pronunciation of the English language, throughout the British dominions, as practised by the most learned and polite speakers. London: Edward \& Charles Dilly.

Cooley, Arnold. 1861. A dictionary of the English language. London \& Edinburgh: W. \& R. Chambers.

Craig, John. 1859. A new universal, etymological, technological, and pronouncing dictionary of the English language. London: Routledge.

Dobson, E. J. 1968. English pronunciation 1500-1700. Vol. 2: Phonology (2nd edn). Oxford: Oxford University Press.

Duchet, Jean-Louis, Nicolas Trapateau \& Jérémy Castanier. 2012. Stress placement in pronouncing dictionaries (1727-2010): Latin etymology vs English derivation. Language \& History, 55(1). 34-46. DOI: 10.1179/1759753612Z.0000000003

Dyche, Thomas. 1723, 1725, 1731, 1737. The spelling dictionary; or, a collection of all the common words and proper names made use of in the English tongue. London: Thomas Norris.

Elphinston, James. 1765. The principles of the English language digested: or, English grammar reduced to analogy. Vol 1. London: P. Vaillant et al.

Entick, John. 1780. The new spelling dictionary, teaching to write and pronounce the English tongue with ease and propriety: A new edition. London: C. Dilly.

Fenning, Daniel. 1761. The Royal English dictionary: or, a treasury of the English language. London: S. Crowder, and Co. 
Houston R. A. \& C. W. J. Withers. 1990. Population mobility in Scotland and Europe, 1600-1900: A comparative perspective. Annales de Démographie Historique 1990. 285-308.

Johnson, Samuel. 1755. A dictionary of the English language; in which the words are deduced from their originals and illustrated in their different significations by examples from the best writers. London: J. \& P. Knaptor.

Johnston, William. 1764. A pronouncing and spelling dictionary. London: W. Johnston.

Jones, Charles. 2006. English pronunciation in the eighteenth and nineteenth centuries. Basingstoke: Palgrave Macmillan. DOI: 10.1057/9780230503403

Jones, Daniel. 1997 [1917]. English pronouncing dictionary. (edited by Peter Roach) Cambridge: Cambridge University Press.

Kenrick, William. 1773. A new dictionary of the English language. London: John \& Francis Rivington et al.

Kenyon, John S. \& Thomas A. Knott. 1945. A pronouncing dictionary of American English. Springfield, IL: G. \& C. Merriam Company.

Labov, William. 1994. Principles of linguistic change. Vol. 1: Internal factors. Oxford: Blackwell.

Labov, William. 2001. Principles of linguistic change. Vol. 2: Social factors. Oxford: Blackwell.

Lass, Roger. 1999. Phonology and morphology. In Roger Lass (ed.), The Cambridge history of the English language, vol. 3: 1476-1776, 56-86. Cambridge: Cambridge University Press.

Mason, George. 1801. A supplement to Johnson's English dictionary: on which the palpable errors are attempted to be rectified, and its material omissions supplied. London: J. White et al.

Milroy, James. 1992. Linguistic variation and change: On the historical sociolinguistics of English. Oxford: Blackwell.

Minsheu, John. 1617. Dictionarium etymologicum: A most copious dictionarie etymological (in eleven languages). London: John Browne.

Mugglestone, Lynda. 2003. Talking proper: The rise of accent as social symbol (2nd edn). Oxford University Press. DOI: 10.1093/acprof:oso/9780199250622.001.0001

Nares, Robert. 1784. Elements of orthoepy: Containing a distinct view of the whole analogy of the English language; so far as it relates to pronunciation, accent, and quantity. London: T. Payne \& Son.

Perry, William. 1775. The Royal standard English dictionary. Edinburgh: The author.

Pouillon, Véronique. 2018. Eighteenth-century pronouncing dictionaries: Reflecting usage or setting their own standard? In Linda Pillière, Wilfrid Andrieu, Valérie Kerfelec \& Diana Lewis (eds), Standardizing English: Norms and margins in the history of the English language, 106-143. Cambridge: Cambridge University Press. DOI: $10.1017 / 9781108120470.006$

Ranson, Rita. 2002. "Elocution Walker", ou la réussite d'un catholique dans l'Angleterre des lumières. Cercles 4. 47-62.

Scott, William. 1786. A new spelling, pronouncing, and explanatory dictionary of the English language. Edinburgh C. Elliot.

Shapiro, Rebecca. 2016. Fixing Babel: An historical anthology of applied English lexicography. Lewisburg, PA: Bucknell University Press.

Sheridan, Thomas. 1762. Lectures on elocution. London: A. Millar et al.

Sheridan, Thomas. 1780, 1789, 1797. A general dictionary of the English language. One main object of which, is, to establish a plain and permanent standard of pronunciation. London: J. Dodsley, C. Dilly \& J. Wilkie. 
Swift, Jonathan. 1712. A proposal for correcting, improving and ascertaining the English tongue. London: Benj. Tooke.

Trapateau, Nicolas. 2015. Placement de l'accent et voyelles inaccentuées dans la prononciation de l'anglais du XVIII ${ }^{e}$ siècle sur la base du témoignage des dictionnaires de prononciation, des vers et de la musique vocale. Unpublished $\mathrm{PhD}$ dissertation: Université de Poitiers.

Trapateau, Nicolas. 2016. 'Pedantick', 'polite', or 'vulgar'? A systematic analysis of eighteenthcentury normative discourse on pronunciation in John Walker's dictionary (1791). Language and History, 59(1). 25-36. DOI: 10.1080/17597536.2016.1189663

Walker, John. 1791. A critical pronouncing dictionary and expositor of the English language. London: G. G. J. \& J. Robinson \& T. Cadell.

Walker, John. 1809. A critical pronouncing dictionary and expositor of the English language. The sixth edition (stereotyped); With considerable improvements, and large additions. London: J. Johnson et al.

Webster, Noah. 1841. An American dictionary of the English language. New York, NY: White \& Sheffield.

Wells, John C. 1982. Accents of English: An introduction. Vol 1. Cambridge: Cambridge University Press.

Wells, John C. 1990, 2000, 2008. Longman pronunciation dictionary. Harlow: Longman Group UK Limited.

Wyld, Henry C. 1906. The historical study of the mother tongue. New York, NY: Haskel House Publishers. 